\title{
Pertumbuhan, Nisbah Kelamin, Faktor Kondisi, dan Struktur Ukuran Ikan Selar Crumenophthalmus dari Perairan Sekitar Bitung
}

\author{
Rudi Saranga ${ }^{1}$ \\ Politeknik Kelautan dan Perikanan Bitung \\ e-mail: rudisaranga@yahoo.com \\ Jenny I. Manengkey ${ }^{2}$ \\ Politeknik Kelautan dan Perikanan Bitung \\ Asia $^{3}$ \\ Politeknik Kelautan dan Perikanan Bitung \\ Muh. Zainul Arifin ${ }^{4}$ \\ Politeknik Kelautan dan Perikanan Bitung
}

\begin{abstract}
ABSTRAK
Penelitian ini bertujuan untuk mengetahui pola pertumbuhan, nisbah kelamin, faktor kondisi, dan struktur ukuran ikan Selar Crumenophthalmus yang tertangkap di perairan sekitar Bitung. Penelitian dilakukan pada bulan Februari-Juli 2016 dengan lokasi pengambilan sampel ikan hasil tangkapan nelayan di Pelabuhan Perikanan Samudera Bitung. Ikan Selar Crumenophthalmus yang dianalisis selama penelitian berjumlah 829 ekor terdiri atas 491 ekor $(59,23 \%)$ ikan jantan dan 331 ekor $(39,939 \%)$ ikan betina serta 7 ekor $(0,84 \%)$ yang tidak teridentifikasi dengan kisaran panjang cagak $\left(\mathrm{F}_{\mathrm{L}}\right)$ antara 10,30-24,30 $\mathrm{cm}$ (rerata $17,66 \pm 3,11 \mathrm{~cm}$ ) dan bobot tubuh berkisar 17,00-259,50 g (rerata 103,82 $\pm 53,88 \mathrm{~g}$ ). Hubungan panjang bobot ikan Selar Crumenopthalmus mengikuti persamaan $\mathrm{W}=0,01166 \mathrm{~F}_{\mathrm{L}}^{3,1320}(\mathrm{R} 2=0,978)$ dengan pola pertumbuhan bersifat allometrik positif $(\alpha=0,05)$ atau pertumbuhan bobot lebih cepat daripada pertumbuhan panjangnya. Persamaan hubungan panjang bobot ikan Selar Crumenopthalmus jantan dan betina masing-masing adalah $\mathrm{W}=0,01065 \mathrm{~F}_{\mathrm{L}}^{3,1667}$ dan $\mathrm{W}=0,01175 \mathrm{~F}_{\mathrm{L}}^{3,1252}$ dengan pola pertumbuhan yang sama, yakni allometrik positif. Nisbah kelamin ikan Selar Crumenopthalmus jantan dan betina adalah 1,48:1. Berdasarkan uji Chi-Square pada selang kepercayaan 95\% $(\alpha=0,05)$ diperoleh bahwa proporsi ikan Selar Crumenopthalmus jantan dan betina yang tertangkap di perairan sekitar Bitung dalam kondisi seimbang. Faktor kondisi relatif $\left(\mathrm{K}_{\mathrm{n}}\right)$ ikan jantan berkisar antara 0,691-1,422 (rerata 1,003 \pm 0,082 ) dan ikan betina $0,701-2,238$ (rerata $1,005+0,112$ ) yang menunjukkan tubuh ikan kurang pipih. Sebaran frekuensi panjang ikan S. crumenophthalmus jantan didominasi pada interval kelas panjang 19$20 \mathrm{~cm}$ dan ikan betina pada interval panjang $20-21 \mathrm{~cm}$.
\end{abstract}

Kata kunci: Sibah kelamin, perairan Bitung, selar crumenophthalmus

\begin{abstract}
This study aims to determine the pattern of growth, sex ratio, factor conditions, and the size structure of the Crumenophthalmus Selar fish caught in the waters around Bitung. The study was conducted in February-July 2016 with the location of sampling of fish caught by fishermen at the Bitung Ocean Fisheries Port. Crumenophthalmus Selar fish analyzed during the study amounted to 829 tails consisting of 491 tails (59.23\%) male fish and 331 tails (39.939\%) female fish and 7 tails $(0.84 \%)$ which were not identified with the long range fork (FL) between 10.30$24.30 \mathrm{~cm}$ (mean $17.66 \pm 3.11 \mathrm{~cm}$ ) and body weight ranged from 17.00-259.50 g (mean $103.82 \pm$ $53.88 \mathrm{~g})$. The relationship of the length of the weight of Selar Crumenopthalmus fish follows the equation $W=0.01166$ FL3.1320 $(R 2=0.978)$ with a positive allometric growth pattern $(\alpha=$ 0.05) or weight growth faster than the growth of its length. The equation of the relationship between the length of the weights of Selar Crumenopthalmus male and female fish is $W=$ 0.01065 FL3.1667 and $W=0.01175$ FL3.1252 with the same growth pattern, which is positive allometric. The sex ratio of fish for male and female Selar Crumenopthalmus is 1.48: 1. Based on the Chi-Square test on a confidence interval of $95 \%(\alpha=0.05)$, it was found that the proportion of male and female Selar Crumenopthalmus fish caught in the waters around Bitung was balanced. Factors of relative conditions (Kn) of male fish ranged from 0.691-1.422 (mean $1.003 \pm 0.082$ ) and female fish 0.701-2.238 (mean 1.005 + 0.112) which showed the body of the
\end{abstract}

Jurnal Frontiers Vol 1 No 3, Desember 2018 
fish was less flat. The frequency distribution of male S. crumenophthalmus fish length was dominated at long class intervals of 19-20 cm and female fish at intervals of length 20-21 cm.

Keywords: Sibah sex, Bitung waters, selar crumenophthalmus

\section{PENDAHULUAN}

Famili Carangidae merupakan ikan pelagis yang tersebar luas di wilayah IndoPasifik. Dilaporkan bahwa kelompok famili Carangidae terdapat 140 spesies dan 32 genus yang tersebar di seluruh perairan dunia (Smith-Vaniz et al., 1999; SmithVaniz, 2003). Perikanan selar di Indonesia termasuk kelompok sumberdaya ikan pelagis kecil dan hidup bergerombol, dimana daerah penyebarannya berada pada wilayah perairan pantai sampai kedalaman 80 meter, hidup di lingkungan perairan pantai landas kontinen, lebih menyukai perairan laut sekitar pulau khususnya perairan neritik, kadang-kadang berada di perairan keruh terutama pada malam hari (Cervigon et al., 1992; Pauly \& Martosubroto, 1996; Froese \& Pauly, 2014; Smith-Vaniz et al., 2015). Perikanan selar menurut standar klasifikasi statistik jenis ikan perikanan laut yang diterbitkan oleh Direktorat Jenderal Perikanan Tangkap (2013), terdiri dari 2 kelompok, yakni selar dan bentong. Kelompok selar terdiri dari satu spesies yakni Selaroides leptolepis, sedangkan kelompok bentong terdiri dari 2 spesies yakni Selar boops dan Selar crumenophthalmus.

Sumberdaya ikan selar jenis $S$. crumenophthalmus merupakan sumberdaya bernilai ekonomis penting di perairan sekitar Bitung. Volume produksi ikan selar di Kota Bitung tahun 2013 mencapai $1.223,5$ ton atau sebesar $21,59 \%$ dari total volume produksi ikan selar di Provinsi Sulawesi Utara yakni sebesar 5.667,70 ton (Dinas KP Kota Bitung, 2014). Total hasil tangkapan ikan selar tahun 2015 yang didaratkan di Pelabuhan Perikanan Samudera Bitung (PPS Bitung) sebesar 704.627 ton dengan nilai produksi mencapai Rp. 13.671.743.000 (PPS Bitung, 2015). Sumberdaya ikan $S$. crumenophthalmus di perairan Bitung menjadi sangat penting karena memberikan nilai kemanfaatan dalam sektor ekonomi dan sosial yang cukup besar, khsusnya pada sektor perikanan. Ikan selar jenis S. crumenophthalmus yang tertangkap di perairan sekitar Bitung memiliki 2 nama lokal yakni Tude untuk ukuran kecil ( $\leq 17,00 \mathrm{~cm}$ FL) dan Oci dengan ukuran yang lebih besar besar $(\geq$ $18,00 \mathrm{~cm}$ FL). Kedua jenis ikan ini meskipun berbeda secara morfologi dan memiliki nama lokal yang berbeda, tetapi berdasarkan kajian genetik dengan analisis DNA-COI merupakan spesies yang sama yakni Selar crumenophthalmus (Saranga dkk, 2016). Permintaan masyarakat terhadap ikan selar terus meningkat meskipun harganya cukup mahal untuk ukuran ikan pelagis yakni mencapai Rp. 40.000 - 50.000 per kg (BPS Kota Bitung, 2016), sehingga hal ini mengakibatkan eksploitasi dilakukan sepanjang tahun untuk memenuhi kebutuhan dan permintaan pasar. Kondisi ini dikuatirkan akan memberikan dapak negatif terhadap pengelolaan dan kelestarian sumberdaya ikan $S$. crumenophthalmus di perairan sekitar Bitung. Informasi aspek biologi ikan S. crumenophthalmus yang tertangkap di perairan sekitar Bitung, perlu diketahui dalam rangka pengelolaan dan pemanfaatan sumberdaya ikan selar. Penelitian ini bertujuan untuk mengetahui pertumbuhan, nisbah kelamin, faktor kondisi, dan struktur ukuran ikan $S$. crumenophthalmus yang tertangkap di perairan sekitar Bitung. 


\section{METODE PENELITIAN}

Penelitian ini dilakukan dengan metode observasi langsung di lapangan pada bulan Februari hingga Juli 2016. Pengumpulan data dilakukan di PPS Bitung yang merupakan pusat pendaratan ikan hasil tangkapan nelayan di Kota Bitung. Jumlah contoh ikan $S$. crumenophthalmus yang dikoleksi yakni 829 ekor. Pengambilan ikan contoh dilakukan setiap bulan sebanyak 100-200 ekor/bulan (rerata 138 ekor/bulan), dengan memperhatikan keterwakilan ukuran ikan yang disampling. Pengambilan ikan contoh dilakukan secara acak dari hasil tangkapan nelayan menggunakan pancing tangan (hand line) yang melakukan operasi penangkapan one day fishing dan mendaratkan hasil tangkapannya di PPS Bitung. Pengukuran sistematis dilakukan dengan mengikuti standar prosedur pengambilan contoh dan pengukuran menurut Kartamihardja (2015). Parameter biologi yang diukur meliputi panjang cagak (FL) dalam satuan $\mathrm{cm}$ menggunakan mistar $(30 \pm 0,1 \mathrm{~cm})$ dan bobot tubuh dalam gram menggunakan timbangan digital $(500 \pm 0,5 \mathrm{~g})$. Pengamatan jenis kelamin dilakukan dengan membedah perut ikan contoh, untuk melihat apakah terdapat sel telur atau testis.

\section{Analisis Data}

\section{a. Pertumbuhan}

Pola pertumbuhan dianalisis berdasarkan hubungan antara panjang bobot dengan mengukur panjang dan bobot ikan yang dikoleksi pada lokasi penelitian. Hubungan panjang dan bobot secara statistik menggunakan bentuk persamaan parabola menurut Froese (2006) :

$$
=\mathrm{aF}_{\mathrm{L}}^{\mathrm{b}}
$$

Dimana, $\mathrm{W}=$ bobot tubuh $(\mathrm{g}), \mathrm{F}_{\mathrm{L}}=$ panjang cagak $(\mathrm{cm}), a$ adalah koefisien bentuk tubuh, dan $b$ adalah eksponen sebagai indikasi hubungan antara panjang bobot dan dimensi pertumbuhan (Mazlan \& Seah, 2006; Kishakudan \& Reddy, 2012). Hubungan $\mathrm{W}=\mathrm{aF}_{\mathrm{L}}{ }^{\mathrm{b}}$ kemudian dikonvensi dalam bentuk logaritma dengan bentuk hubungan garis lurus dengan persamaan :

$\log \mathrm{W}=\log \mathrm{a}+\mathrm{b} \log \mathrm{L}$ (2)

Nilai "b" sebagai indikasi laju pertumbuhan. Jika $b=3, \quad F_{L}$ dan $W$ memiliki laju pertumbuhan yang sama (isometrik); jika $b>3$, pertumbuhan lebih cepat dari pertambahan panjang (positive allometry); jika $\mathrm{b}<3$, pertumbuhannya lebih lambat dari pertambahan panjang (negative allometry). Untuk menguji nilai ' $b$ ' apakah sama dengan ' 3 ', dilakukan uji t-student's untuk memprediksi tingkat signifikan (Snedecor \& Cochran 1967 dalam Panda et al., 2015). Statistik uji t-statistik dihitung dengan persamaan sebagai berikut :

$\mathrm{t}=(\mathrm{b}-3) / \mathrm{S}_{\mathrm{b}}$

dimana, $\mathrm{S}_{\mathrm{b}}=$ Standard error dari nilai ' $\mathrm{b}$ ' dengan persamaan $\left(S_{\mathrm{b}}\right)=\sqrt{ }(1 /(\mathrm{n})) \times$ $\left[(\mathrm{Sy} / \mathrm{Sx})^{2}-\mathrm{b}^{2}\right]$, Sx dan Sy adalah standard deviasi dari $\mathrm{x}$ (panjang) dan $\mathrm{y}$ (bobot). Nilai t hitung dibandingkan dengan nilai ttable untuk (n-2) dengan derajat tingkat kepercayaan signifikan sebesar 5\% $(\alpha=$ $0,05)$.

\section{b. Nisbah Kelamin}

Untuk mengetahui apakah proporsi ikan jantan dan betina dalam kondisi seimbang yakni $1: 1$, digunakan uji ChiSquare $\left(X^{2}\right)$ (Ayo-Olalusi, 2014) dengan tingkat kepercayaan $95 \% \quad(\alpha=0,05)$ 
dengan prosedur pengujian :

$\mathrm{H}_{\mathrm{o}}$ : perbandingan ikan jantan dan betina adalah $1: 1$

$\mathrm{H}_{1}$ : perbandingan ikan jantan dan betina bukan $1: 1$

Kriteria pengujian: jika $X_{\text {hitung }}^{2}>X_{\text {tabel }}^{2}$ maka $\mathrm{H}_{\mathrm{o}}$ diterima, sebaliknya jika $X^{2}{ }_{\text {hitung }}<$

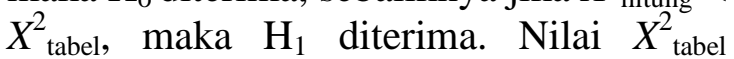
menggunakan derajat bebas $(\mathrm{db})=2-1=1$ sehingga diperoleh nilai $X_{\text {tabel }}^{2}(0,05: 1)=$ 3,841 .

\section{c. Faktor Kondisi}

Nilai faktor kondisi (K) pada ikan yang berbadan agak pipih atau compressed berkisar antara 2,0 - 4,0 sedangkan pada ikan yang kurang pipih atau fusiform berkisara antara 1,0 - 3,0 (Effendie, 1997). Nilai faktor kondisi dihitung berdasarkan hubungan panjang bobot dengan menggunakan faktor kondisi relatif $\left(\mathrm{K}_{\mathrm{n}}\right)$, yaitu:

$\mathrm{K}_{\mathrm{n}}=\mathrm{W} / \mathrm{W} \_$est

dimana:

$\mathrm{K}_{\mathrm{n}} \quad$ = faktor kondisi relatif

$\mathrm{W} \quad=$ bobot ikan contoh $(\mathrm{g})$

W_est $=$ bobot ikan contoh estimasi (W_est $=\mathrm{aF}_{\mathrm{L}}^{\mathrm{b}}$ )

\section{HASIL DAN PEMBAHASAN a. Pertumbuhan}

Ukuran panjang cagak $\left(\mathrm{F}_{\mathrm{L}}\right)$ ikan maksimum yang tertangkap mencapai $24,30 \mathrm{~cm}$ dan ukuran minimum $10,30 \mathrm{~cm}$ (rerata 17,66 $\pm 3,11 \mathrm{~cm}$ ) dengan bobot minumum $17,00 \mathrm{~g}$ dan bobot maksimum
$259,50 \mathrm{~g}$ (rerata 103,82 \pm 53,88 g). Morfologi ikan S. crumenophthalmus secara visual disajikan pada Gambar 1. Persamaan hubungan panjang bobot pada ikan S. crumenophthalmus secara keseluruhan (Gambar 2a) diperoleh $\mathrm{W}=$ $0,01166 \mathrm{~F}_{\mathrm{L}}{ }^{3,1320}$, dengan jumlah sampel ikan 892 ekor dan nilai $\mathrm{R}^{2}=0,9780$ yang memiliki pengertian bahwa variasi bobot ikan dapat dijelaskan atau dipengaruhi oleh variasi panjang ikan sebesar 97,80\% dan nilai Standart Error b (SEb) sebesar 0,0163 yang menjelaskan bahwa kecilnya penyimpangan koefisien regresi variabel panjang ikan dan telah memberikan kontribusi yang signifikan terhadap varibel bobot ikan, dengan nilai signifikan dalam uji $\mathrm{F}$ diperoleh $\mathrm{p}<0,05$. Persamaan hubungan panjang bobot pada ikan jantan (Gambar 2b) diperoleh $\mathrm{W}=0,01065$ $\mathrm{F}_{\mathrm{L}}^{3,1667}$ dengan jumlah sampel ikan 491 ekor dan nilai $\mathrm{R}^{2}=0,9838$ yang memiliki pengertian bahwa variasi bobot ikan dapat dijelaskan atau dipengaruhi oleh variasi panjang ikan sebesar 98,38\% dan nilai Standart Error b (SEb) sebesar 0,0183 yang menjelaskan bahwa kecilnya penyimpangan koefisien regresi variabel panjang ikan dan telah memberikan kontribusi yang signifikan terhadap varibel bobot ikan, dengan nilai signifikan dalam uji $F$ diperoleh $p<0,05$. Hasil persamaan hubungan panjang bobot ikan betina (Gambar 2c) diperoleh $\mathrm{W}=0,01175$ $\mathrm{F}_{\mathrm{L}}^{3,1252}$ dengan jumlah sampel ikan 331 ekor dan nilai $\mathrm{R}^{2}=0,9611$ yang berarti bahwa variasi bobot ikan dapat dijelaskan atau dipengaruhi oleh variasi panjang ikan sebesar 96,11\% dan nilai Standart Error b (Seb) sebesar 0,0347 yang menunjukkan kecilnya penyimpangan koefisien regresi variabel panjang ikan dan memberikan kontribusi yang signifikan terhadap varibel bobot ikan, dengan nilai signifikan dalam uji $\mathrm{F}$ diperoleh $\mathrm{p}<0,05$. 


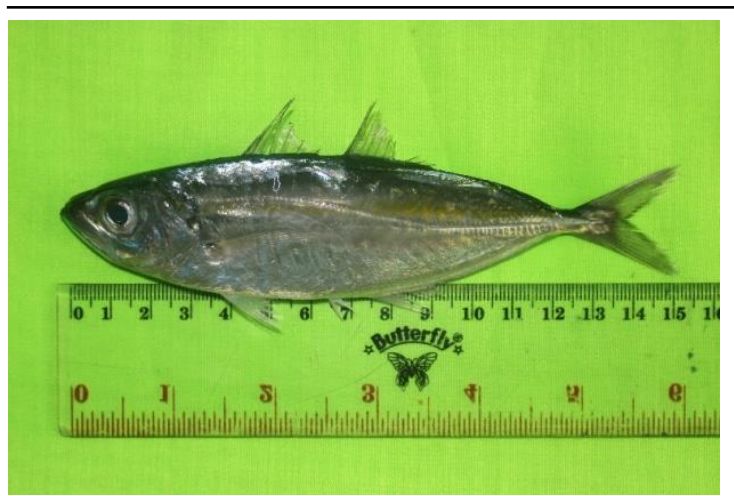

Gambar 1. Visualisasi morfologi ikan $S$. crumenophthalmus

Hasil perhitungan uji $\mathrm{t}$ terhadap nilai $b \quad(\alpha=0,05)$ pada ikan jantan didapatkan $t_{\text {hitung }}$ sebesar 9,085 dan $t_{\text {tabel }}$ $(0,05 ; 483)$ sebesar 1,97 sehingga $t_{\text {hitung }}>$ $\mathrm{t}_{\text {tabel }}$ bahwa pola pertumbuhan ikan $S$. crumenophthalmus jantan bersifat allometrik positif dengan kisaran nilai $b$ yakni 3,1306 - 3,2027. Sedangkan untuk ikan betina didapatkan hasil $t_{\text {hitung }}$ yakni 3,612 dengan $t_{\text {tabel }}(0,05 ; 329)$ sebesar 1,97 maka $t_{\text {hitung }}>t_{\text {tabel }}$ sehingga pola pertumbuhan ikan S. crumenophthalmus betina bersifat allometrik positif dengan kisaran nilai b yakni $3,0570-3,1934$. Berdasarkan uji $\mathrm{t}$ terhadap nilai $\mathrm{b}(\alpha=$ $0,05)$, didapatkan pola pertumbuhan bentuk tubuh pada ikan jantan dan betina sama-sama memiliki pola pertumbuhan allometrik positif yakni pola pertumbuhan dimana pertambahan bobotnya lebih dominan dibandingkan pertambahan panjangnya (Effendie, 1997). Analisis kovarian nilai $\mathrm{b}$ berdasarkan hubungan panjang bobot antara ikan jantan dan betina menunjukkan tidak ada perbedaan yang signifikan $(p>0,05)$. Hasil nilai $b$ yang didapatkan dalam penelitian ini hampir sama dengan beberapa penelitian terdahulu, seperti hasil yang didapat di sekitar Pulau Reunion, Samudra Hindia barat daya (Roos et al., 2007) dengan nilai (b) ikan jantan 3,2247 dan (b) ikan betina 3,3695 dengan pola pertumbuhan allometrik positif; Panda et al. (2015) di perairan Mumbai India mendapatkan nilai (b) keseluruhan 3,37 serta nilai (b) jantan 3,34 dan nilai (b) betina 3,39 dengan pola pertumbuhan allometrik positif; Echem \& Minoza (2017) di bagian barat Mindano Filipina mendapatkan nilai (b) (jantan dan betina) 3,29 (FL).
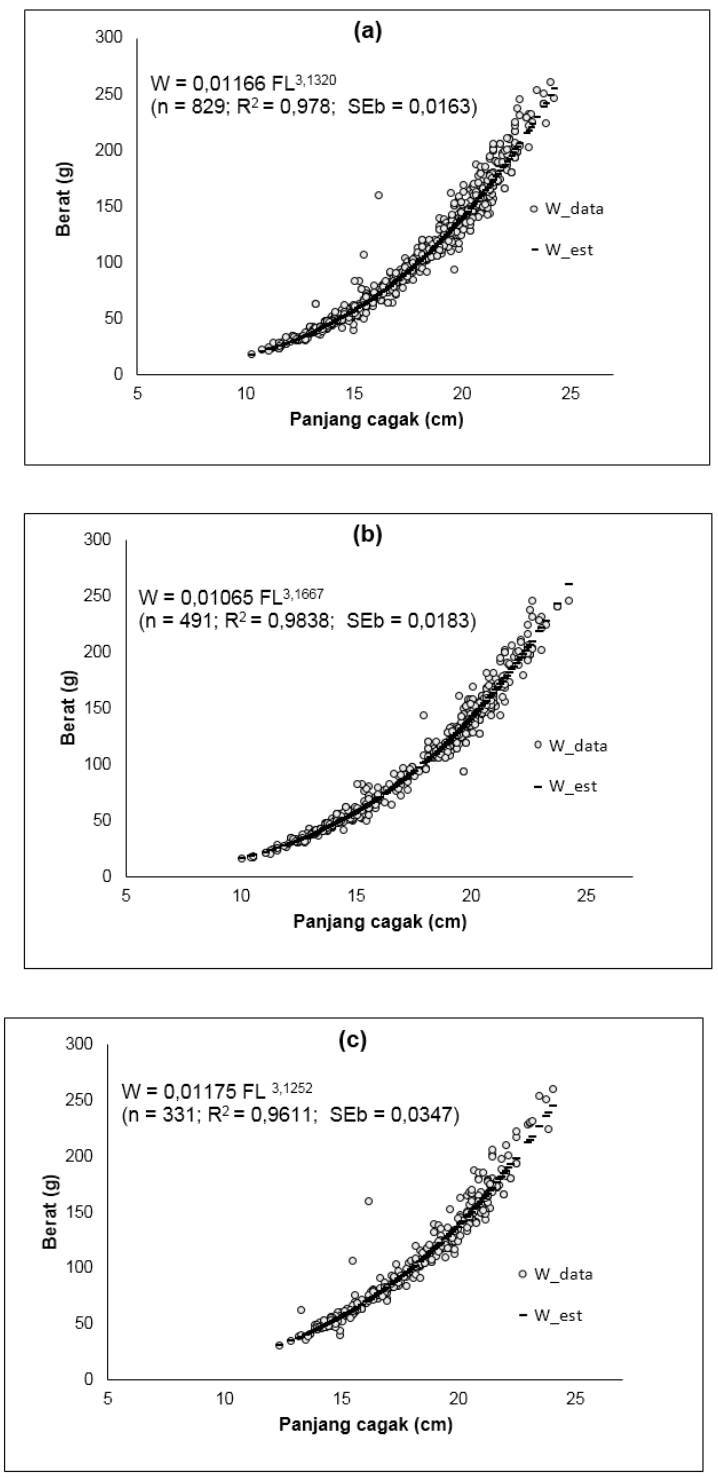

Gambar 2 (a). Hubungan panjang bobot ikan S. crumenophthalmus (jantan dan betina)

(b). Hubungan panjang bobot ikan $S$. crumenophthalmus jantan

(c). Hubungan panjang bobot ikan $S$. crumenophthalmus betina 
Pertumbuhan ikan $S$. crumenophthalmus (Tabel 1) di perairan sekitar Bitung selama penelitian berdasarkan nilai $b$ bervariasi setiap bulannya. Hubungan panjang bobot dapat dipengaruhi oleh fase pertumbuhan ikan, ukuran ikan, ketersediaan makanan, jenis kelamin, perkembangan gonad, kesehatan ikan, dan periode pemijahan (Miranda et al., 2006; Andreu-Soler et al., 2006; Tsoumani et al., 2006). Menurut Kharat et al., (2008) bahwa interaksi panjang dan bobot pada ikan dapat juga disebabkan oleh perbedaan jumlah dan variasi ukuran ikan yang dijadikan sebagai contoh. Menurut Bagenal \& Tesch (1978) dan Tsoumani et al. (2006) bahwa perbedaan nilai $b$ dapat pula disebabkan oleh adanya perbedaan jenis kelamin ikan.

Tabel 1. Hubungan panjang bobot ikan $S$. crumenophthalmus bulan Februari - Juli 2016

\begin{tabular}{lll}
\hline Bulan & \multicolumn{1}{c}{ Jantan } & \multicolumn{1}{c}{ Betina } \\
& & \\
\hline Februari & $\mathrm{W}=0,00863$ & $\mathrm{~W}=0,00874$ \\
& $\mathrm{~F}_{\mathrm{L}}^{3,2311}$ & $\mathrm{~F}_{\mathrm{L}}^{3,2245}$ \\
Maret & $\mathrm{W}=0,01367$ & $\mathrm{~W}=0,02192$ \\
& $\mathrm{~F}_{\mathrm{L}}^{3,0845}$ & $\mathrm{~F}_{\mathrm{L}}^{2,9991}$ \\
April & $\mathrm{W}=0,01035$ & $\mathrm{~W}=0,01007$ \\
& $\mathrm{~F}_{\mathrm{L}}^{3,1808}$ & $\mathrm{~F}_{\mathrm{L}}^{3,1933}$ \\
Mei & $\mathrm{W}=0,01522$ & $\mathrm{~W}=0,01101$ \\
& $\mathrm{~F}_{\mathrm{L}}^{3,0464}$ & $\mathrm{~F}_{\mathrm{L}}^{3,1494}$ \\
Juni & $\mathrm{W}=0,00891$ & $\mathrm{~W}=0,01370$ \\
& $\mathrm{~F}_{\mathrm{L}}^{3,2286}$ & $\mathrm{~F}_{\mathrm{L}}^{3,0621}$ \\
\multirow{2}{*}{ Juli } & $\mathrm{W}=0,00928$ & $\mathrm{~W}^{3}=0,00985$ \\
& $\mathrm{~F}_{\mathrm{L}}^{3,2150}$ & $\mathrm{~F}_{\mathrm{L}}^{3,1730}$ \\
\hline
\end{tabular}

Hasil yang didapatkan pada Tabel 1 menginformasikan bahwa secara umum pola pertumbuhan ikan $S$. crumenophthalmus bersifat allometik positif, yakni bobot tubuh lebih cepat berkembang dibandingkan dengan panjang tubuh. Ada hal menarik yang terjadi pada bulan Maret dimana ikan betina memperoleh nilai $b=2,9191(b<3)$ dan hasil uji $\mathrm{t}$ terhadap nilai $\mathrm{b}$ menunjukkan pertumbuhan allometrik negatif, yakni pertambahan bobot sedikit lebih lambat dari pertambahan panjangnya. Kondisi ini ada kaitannya dengan fase musim pemijahan, dimana ikan $S$. crumenophthalmus betina pada saat memasuki periode musim pemijahan, sebagaian besar aktivitas metabolisme tubuhnya akan ditujukan untuk perkembangan gonad sampai pada selesainya musim pemijahan, sehingga hal ini diduga mempengaruhi pertumbuhan ikan betina. Menurut Effendie (1997) bahwa pertumbuhan mempengaruhi kondisi ikan pada saat mencapai ukuran pertama kali matang gonad, dimana kecepatan pertumbuhannya menjadi sedikit lambat karena sebagian dari makanan yang dimakan ditujukan untuk perkembangan gonadnya. Berdasarkan hasil ini bahwa periode musim pemijahan ikan $S$. cumenophthalmus di perairan

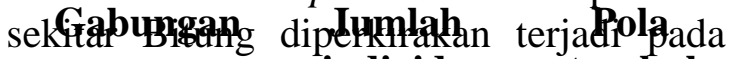
bulan April. indiyidu bupertumaukan diperiRiegarah2 bahwa 14Ran suAthomettridi Fiemasuki ukuran pertama kalippsititing

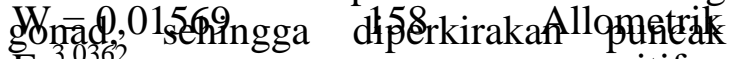
Hintusim pemijahan akan terjadi apsitifian

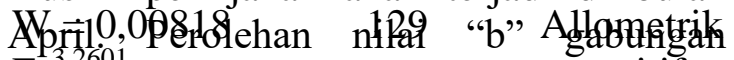
$F_{j}^{3}$ thtan dan betina) tertinggi juga dipsititifeh pdō Q Fal' ini mengindikasikan bahwa pallasibitifian

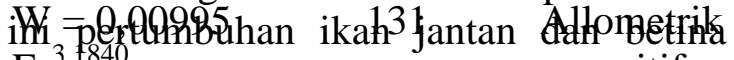
Filencapai kondisi terbaik posititiena

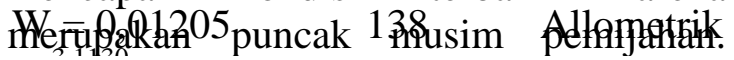
Venkataramani et al. (1995) melaporkan bahwa musim pemijahan ikan $S$. cumenophthalmus di India berlangsung hampir sepanjang tahun, yakni antara bulan Maret-Juli, dengan 2 puncak yaitu antara bulan Juli-Oktober dan bulan Januari-April, selanjutnya Siwat et al. (2017) melaporkan bahwa musim pemijahan ikan S. crumenophthalmus di perairan Semarang Indonesia berdasarkan 
indeks kematangan gonad terjadi pada bulan April-Juni.

\section{b. Nisbah Kelamin}

Jumlah total ikan sampel yang dikoleksi dari bulan Februari 2016 sampai dengan bulan Juli 2016 berjumlahi 829 ekor, terdiri dari ikan jantan 491 ekor $(59,23 \%)$, ikan betina 331 ekor $(39,93 \%)$, dan tidak terindenfikasi 7 ekor $(0,84 \%)$. Berdasarkan hasil analisis perbandingan jenis kelamin, diperoleh bahwa ikan jantan lebih banyak dibandingkan ikan betina dengan perbandingan $0,60: 0,40$. Hal ini berarti bahwa setiap 1 ekor ikan jantan terdapat 1 ekor ikan betina $(1,48: 1)$ (Gambar 3). Analisis chi-kuadrat $\left(X^{2}\right)$ menggunakan $\alpha=0,05$ diperoleh nilai hitung $X^{2}=31,14$ dan nilai tabel $X_{(0,05: 1)}=$ 3,841 ( $X^{2}$ hitung $>X^{2}$ tabel $)$ sehingga $\mathrm{H}_{\mathrm{o}}$ diterima bahwa tidak terdapat perbedaan rasio antara ikan jantan dan betina. Roos et al. (2007) melaporkan bahwa rasio kelamin ikan $S$. crumenophthalmus di perairan pulau Reunion konstan dari bulan ke bulan.
Perbandingan jenis kelamin ikan yang hidup bergerombol mencapai kondisi optimal apabila ikan betina dan ikan jantan berbanding 2:1 (Rahman dkk., 2013). Ball \& Rao (1984) menyatakan bahwa untuk mempertahankan kelangsungan hidup dalam suatu populasi, perbandingan ikan jantan dan betina diharapkan berada dalam kondisi seimbang yakni 1:1, setidaknya ikan betina lebih banyak dari jantan. Hasil perbandingan nisbah kelamin ikan jantan dan betina yang diperoleh dalam penelitian secara umum dalam kondisi seimbang, namun untuk kondisi optimal dalam mempertahankan keberlanjutan sumberdaya, mengindikasikan bahwa terjadi ketidakseimbangan proporsi, sehingga hal ini dapat menganggu populasi sumberdaya ikan $S$. crumenophthalmus yang ada di perairan sekitar Bitung, khususnya dalam proses reproduksi dan rekrutmen. Menurut Wilson \& Clarke (1996), eksploitasi yang semakin meningkat dan tekanan terhadap lingkungan dapat menyebabkan perubahan rasio jenis kelamin dan keseimbangan interspesifik ikan.

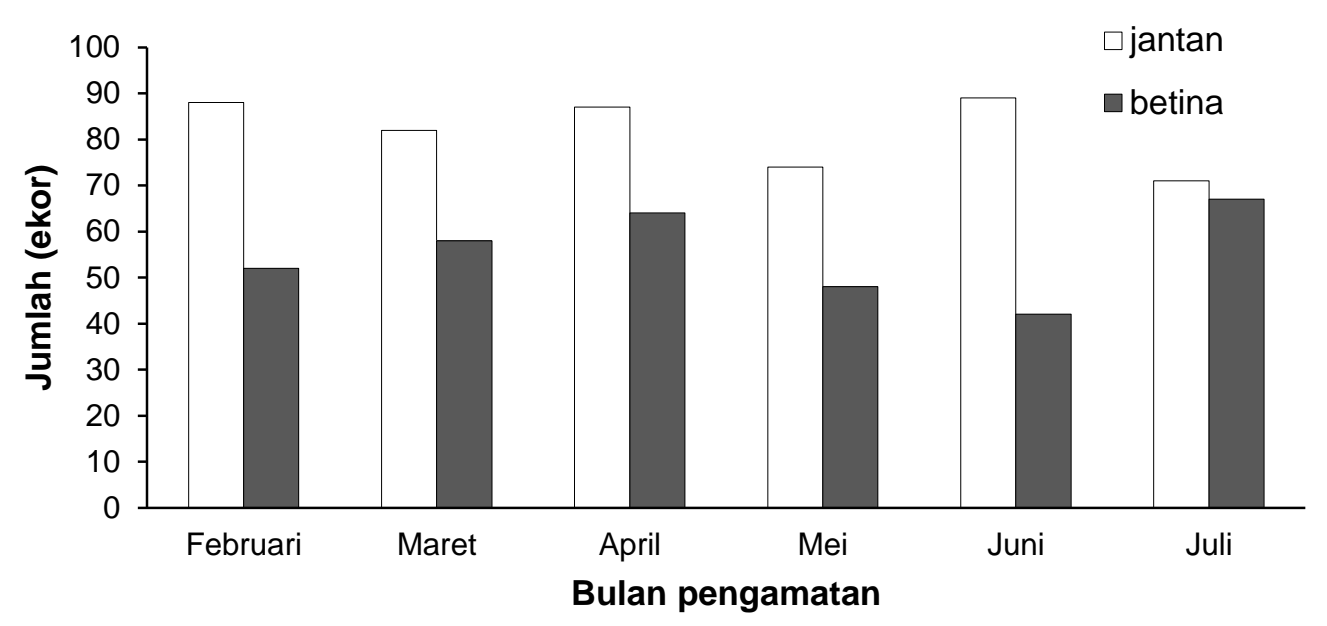

Gambar 3. Perbandingan jumlah ikan S. crumenophthalmus jantan dan betina 


\section{c. Faktor Kondisi}

Nilai faktor kondisi relatif $\left(\mathrm{K}_{\mathrm{n}}\right)$ ikan S. crumenophthalmus jantan selama pengamatan diperoleh pada kisaran 0,6911,422 (rerata $1,003 \pm 0,082$ ), sedangkan ikan betina pada kisaran 0,701-2,238 (rerata $1,005 \pm 0,112$ ). Faktor kondisi relatif ikan $S$. crumenophthalmus jantan dan betina mengalami fluktuasi berdasarkan bulan pengamatan (Gambar 4). Nilai rerata $\mathrm{K}_{\mathrm{n}}$ ikan $S$. crumenophthalmus jantan terendah terjadi di bulan Februari yakni 0,978), kemudian mengalami kenaikan pada bulan Maret sebesar 1,014. Pada bulan Maret-Mei nilai $\mathrm{K}_{\mathrm{n}}$ lebih stabil, yakni berturut-turut 1,014; 1,016; dan 1,014 sedangkan pada bulan Juni-Juli kembali mengalami penurunan, yakni 0,999 dan 1,001. Nilai $K_{n}$ ikan $S$. crumenophthalmus betina terendah terjadi di bulan Februari yakni 0,987 kemudian mengalami kenaikan pada bulan MaretApril sebesar 1,031 dan 1,053. Pada bulan Mei-Juli mengalami penurunan kembali yakni berturut-turut 1,011; 0,972; dan 0,966. Nilai $\mathrm{K}_{\mathrm{n}}$ yang rendah menunjukkan kondisi ikan yang sangat ekstrim, sedangkan nilai $\mathrm{K}_{\mathrm{n}}$ yang tinggi menunjukkan kondisi yang prima dari ikan sampling (Panda et al., 2015). Faktor kondisi merupakan salah satu petunjuk penting dari pertumbuhan ikan, sehingga berdasarkan analisis nilai $\mathrm{K}_{\mathrm{n}}$ berbasis ukuran panjang ikan menunjukkan bahwa ikan jantan lebih stabil dibandingkan ikan betina. Effendie (1997) menyatakan bahwa faktor kondisi menggambarkan keadaan ikan, baik ditinjau dari aspek fisiologis untuk kelangsungan hidup maupun reproduksi.

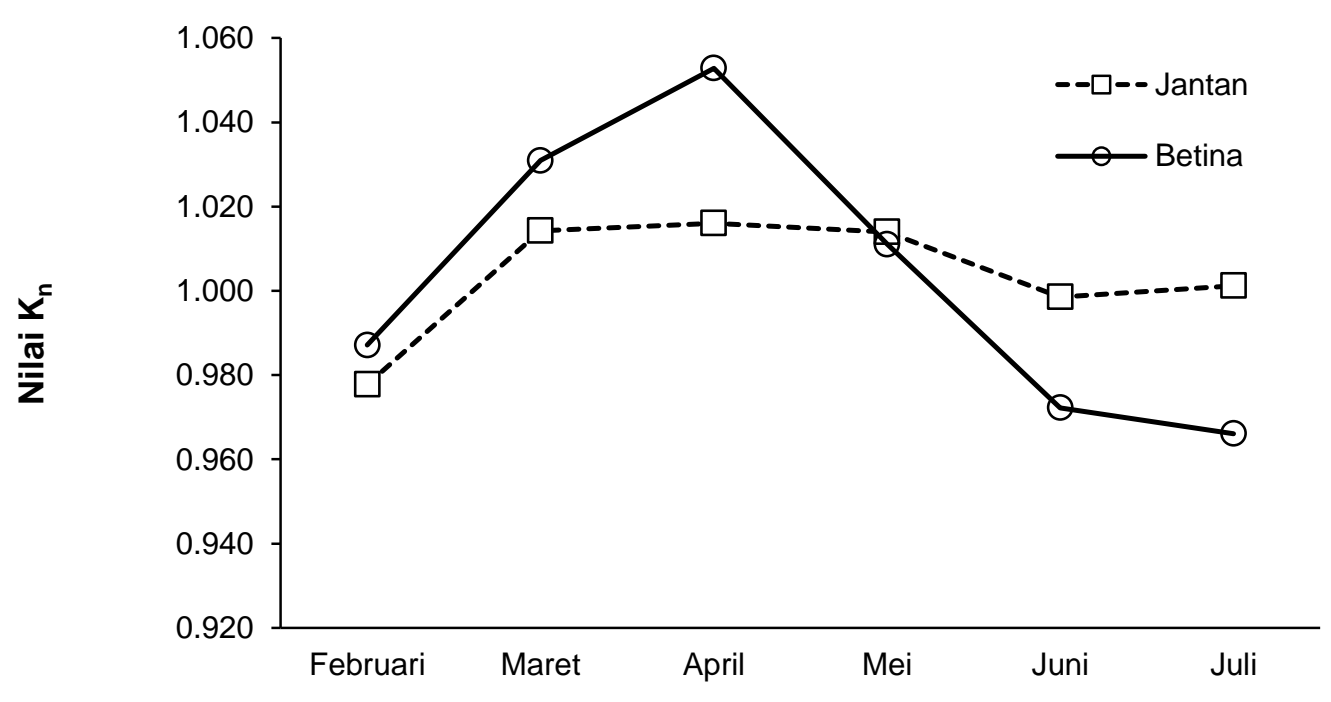

Bulan pengamatan

Gambar 4. Fluktuasi nilai rerata $\mathrm{K}_{\mathrm{n}}$ bulanan berdasarkan waktu pengamatan

Pada bulan Februari didapatkan nilai $\mathrm{K}_{\mathrm{n}}$ yang rendah pada ikan jantan dan betina, hal ini menunjukkan bahwa ikan yang tertangkap pada bulan ini berada pada kondisi yang kurang baik atau kurang proporsional, sehingga mempengaruhi nilai $\mathrm{K}_{\mathrm{n}}$ yang diperoleh. Hal ini didukung oleh hasil pengamatan terhadap ikan yang tertangkap selama penelitian berdasarkan distribusi panjang cagak yang 
menginformasikan bahwa ikan yang tertangkap pada bulan Februari dan Maret umumnya berukuran muda sehingga diperkirakan masih dalam tahap perkembangan menuju ukuran ikan dewasa. Selain itu, banyaknya ikan muda dalam kondisi belum matang gonad yang tertangkap juga mempengaruhi rendahnya nilai $\mathrm{K}_{\mathrm{n}}$ ikan $S$. crumenophthalmus jantan dan betina pada bulan Februari. Nilai $\mathrm{K}_{\mathrm{n}}$ tertinggi ikan jantan dan betina terjadi pada bulan April, hal ini disebabkan banyaknya ikan dewasa yang tertangkap pada bulan April, sehingga dapat diperkirakan bahwa pada bulan ini merupakan puncak musim pemijahan karena kondisi ikan sangat prima berdasarkan tingginya nilai $\mathrm{K}_{\mathrm{n}}$ jika dibandingkan nilai $\mathrm{K}_{\mathrm{n}}$ pada bulan yang lain. Lemma et al. (2015) menyatakan bahwa faktor kondisi mewakili sebuah indikator yang mencerminkan interaksi antara faktor biotik dan abiotik terhadap kondisi fisiologis ikan, dengan asumsi bahwa ikan yang memiliki nilai faktor kondisi lebih besar menunjukkan keadaan fisiologis yang lebih sehat. Clarke \& Privitera (1995) melaporkan bahwa musim pemijahan ikan S. crumenophthalmus di perairan Hawai terjadi di bulan AprilOktober. Mansor et al. (1996) melaporkan bahwa musim pemijahan ikan $S$. crumenophthalmus di Semenanjung Malaysia pada tahun 1993 terjadi di bulan April-Mei dan bulan NovemberDesember, sedangkan tahun 1994 terjadi di bulan Februari-Maret dan bulan Agustus - Oktober.

Selanjutnya nilai $\mathrm{K}_{\mathrm{n}}$ pada ikan betina turun secara signifikan pada periode bulan Mei-Juli, yakni bertutur-turut 1,011; 0,$972 ; 0,966$. Hal ini diperkirakan oleh karena ikan betina telah selesai melakukan aktivitas pemijahan pada bulan April sehingga mempengaruhi nilai $K_{n}$ yang diperoleh. Menurut Anderson \& Gutreuter
(1983) bahwa perbedaan yang terjadi pada nilai $\mathrm{K}_{\mathrm{n}}$ dapat menggambarkan kondisi indeks kematangan gonad dan musim pemijahan dari ikan. Panda et al. (2015) menyatakan bahwa penurunan nilai $\mathrm{K}_{\mathrm{n}}$ pada ikan betina kemungkinan disebabkan oleh karena penurunan berat badan akibat kondisi stres pada saat pemijahan. Perbedaan nilai $\mathrm{K}_{\mathrm{n}}$ diinterpretasikan sebagai indikator dari berbagai sifat-sifat biologi dari ikan, seperti kegemukan, kesesuaian dengan lingkungan, dan perkembangan gonad (Le Cren, 1951 dalam Merta,1993).

\section{d. Struktur Ukuran Ikan}

Sebaran ukuran panjang cagak $\left(\mathrm{F}_{\mathrm{L}}\right)$ ikan S. crumneophthalmus yang terukur dalam penelitian mempunyai ukuran panjang cagak minimum $10,30 \mathrm{~cm}$ dan maksimum 24,30 cm (rerata 17,66 $\pm 3,11$ $\mathrm{cm})$. Sebaran distribusi frekuensi panjang ikan $S$. crumenophthalmus jantan yang tertangkap selama penelitian terdapat pada interval panjang kelas 10-25 cm sedangkan ikan betina pada interval panjang kelas 12-25 cm (Gambar 5). Ikan jantan dengan 3 (tiga) frekuensi tertinggi berturut-turut terdapat pada interval kelas panjang 19-20 cm sebanyak 79 ekor (16,09\%); interval kelas panjang 20-21 cm sebanyak 64 ekor (13,03\%); dan interval kelas panjang 13-14 cm sebanyak 58 ekor $(11,81 \%)$. Ikan betina dengan 3 (tiga) frekuensi tertinggi berturut-turut terdapat pada tengah kelas panjang 20-21 cm sebanyak 47 ekor $(14,20 \%)$; interval kelas panjang 19-20 cm sebanyak 45 ekor $(13,60 \%)$; dan interval kelas panjang $14-$ $15 \mathrm{~cm}$ sebanyak 43 ekor $(12,99 \%)$. Ikan jantan mulai tertangkap pada ukuran interval kelas panjang 10-11 $\mathrm{cm}$ dan 11-12 $\mathrm{cm}$, sedangkan ikan betina mulai tertangkap pada interval kelas panjang 12$13 \mathrm{~cm}$. Berdasakan hasil ini dapat diinformasikan bahwa ukuran ikan jantan 
yang tertangkap lebih kecil beberapa $\mathrm{cm}$ dari ukuran ikan betina yang tertangkap berdasarkan jenis kelamin

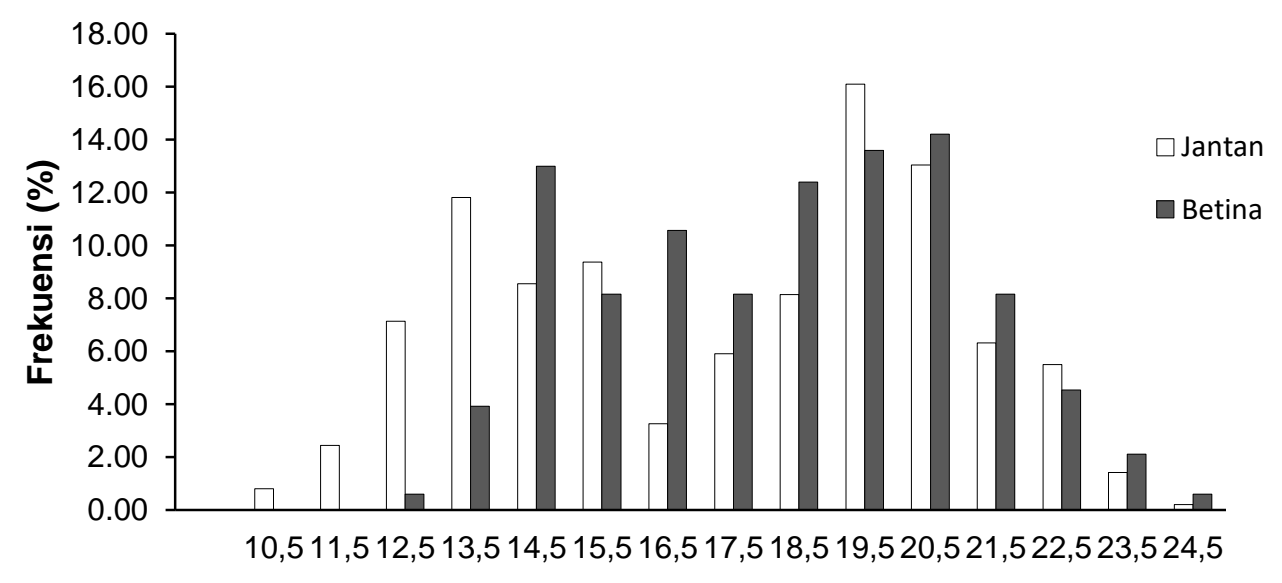

Interval tengah kelas panjang cagak (cm)

Gambar 5. Sebaran distribusi panjang cagak ikan S. crumenophthalmus

Sebaran distribusi panjang cagak ikan $S$. crumenophthalmus keseluruhan (Tabel 2) menginformasikan bahwa frekuensi tertinggi ikan yang tertangkap pada interval kelas 19-20 cm sebanyak 107 ekor dengan persentase $12,91 \%$ dan pada interval kelas 20-21 cm sebanyak 102 ekor dengan persentase $12,30 \%$. Hasil ini menunjukkan bahwa umumnya ukuran ikan yang tertangkap telah mencapai ukuran dewasa, bahkan diperkirakan telah memasuki usia matang gonad untuk melakukan pemijahan. Clarke \& Privitera (1995) melaporkan bahwa pada musim pemijahan ikan S. crumenophthalmus di perairan Hawai ukuran ikan pertama kali matang gonad $<20 \mathrm{~cm}$ SL. Roux \& Conand (2000) melaporkan bahwa ukuran ikan S. crumenophthalmus di perairan pulau Reunion pada musim pemijahan dalam satu tahun mencapai ukuran panjang cagak rerata $21,5 \mathrm{~cm}$ dan hanya sedikit yang mencapai umur satu tahun. Roos et al., (2007) melaporkan bahwa ikan S. crumenophthalmus di perairan pulau Reunion mencapai ukuran matang gonad pada panjang cagak 21,5 $\mathrm{cm}$.

Tabel 2. Distribusi frekuensi bulanan panjang cagak ikan S. crumenophthalmus

\begin{tabular}{crrrrrrrr}
\hline \multirow{2}{*}{$\begin{array}{c}\text { Tengah } \\
\text { Kelas }\end{array}$} & Februari & Maret & April & Mei & Juni & Juli & Jumlah & $\begin{array}{c}\text { Persentase } \\
(\%)\end{array}$ \\
\hline $10-11$ & 0 & 2 & 0 & 0 & 0 & 0 & 2 & 0,24 \\
$11-12$ & 6 & 8 & 3 & 0 & 4 & 0 & 21 & 2,53 \\
$12-13$ & 4 & 11 & 2 & 4 & 10 & 4 & 35 & 4,22 \\
$13-14$ & 13 & 19 & 5 & 11 & 17 & 8 & 73 & 8,81 \\
\hline
\end{tabular}


R. Saranga, J.I. Manengkey, Asia. Jurnal Sains dan Teknologi, Universitas Negeri Manado \& M. Z. Arifin

www.unima.ac.id/lppm/efrontiers

\begin{tabular}{crrrrrrrr}
\hline $14-15$ & 23 & 9 & 7 & 18 & 11 & 10 & 78 & 9,41 \\
$15-16$ & 21 & 3 & 13 & 12 & 8 & 27 & 84 & 10,13 \\
$16-17$ & 9 & 7 & 27 & 1 & 7 & 16 & 67 & 8,08 \\
$17-18$ & 11 & 7 & 18 & 7 & 6 & 9 & 58 & 7,00 \\
$18-19$ & 6 & 16 & 15 & 12 & 16 & 13 & 78 & 9,41 \\
$19-20$ & 11 & 24 & 13 & 21 & 20 & 18 & 107 & 12,91 \\
$20-21$ & 18 & 16 & 14 & 21 & 14 & 19 & 102 & 12,30 \\
$21-22$ & 14 & 19 & 7 & 8 & 10 & 14 & 72 & 8,69 \\
$22-23$ & 8 & 13 & 5 & 6 & 5 & 0 & 37 & 4,46 \\
$23-24$ & 3 & 4 & 0 & 3 & 3 & 0 & 13 & 1,57 \\
$24-25$ & 1 & 0 & 0 & 1 & 0 & 0 & 2 & 0,24 \\
\hline Total & $\mathbf{1 4 8}$ & $\mathbf{1 5 8}$ & $\mathbf{1 2 9}$ & $\mathbf{1 2 5}$ & $\mathbf{1 3 1}$ & $\mathbf{1 3 8}$ & $\mathbf{8 2 9}$ & $\mathbf{1 0 0}$ \\
\hline
\end{tabular}

Distribusi ukuran panjang cagak bulanan (Gambar 6), menginformasikan bahwa ukuran ikan yang tertangkap pada panjang kelas 10-25 cm, dengan ukuran panjang ikan terkecil yang tertangkap pada interval kelas panjang $10-11 \mathrm{~cm}$ dan ukuran panjang ikan terbesar didapatkan pada interval kelas panjang 24-25 cm. Pada bulan Februari perbandingan ukuran hasil tangkapan ikan pada panjang kelas 10-17 cm (kategori ikan muda) dan pada panjang kelas $18-25 \mathrm{~cm}$ (kategori ikan dewasa) yakni $58,78 \%$ dan $41,22 \%$ $(1: 0,70)$, sedangkan perbandingan ikan muda dan dewasa pada bulan Maret yakni $41,77 \%$ dan 58,23\% (1:1,39). Hasil ini menginformasikan bahwa pada bulan Februari jumlah ikan muda sedikit lebih banyak dari ikan dewasa, sedangkan pada bulan Maret jumlah ikan dewasa sedikit lebih banyak dari ikan muda, dengan kata lain bahwa terjadi proses pertumbuhan ikan dari ikan muda menjadi ukuran ikan dewasa meskipun perubahan yang terjadi relatif kecil. Hal ini diduga bahwa pada bulan Februari merupakan masa rekrutmen hasil dari pemijahan pada bulan-bulan sebelumnya, yang diperkirakan terjadi antara bulan Agustus-Oktober. Roux \& Conand (2000) melaporkan bahwa ikan $S$. crumenophthalmus di perairan pulau Reunion memiliki siklus reproduksi tahunan, dimana pemijahan terjadi sebagian besar pada bulan OktoberDesember. Venkataramani et al. (1995) melaporkan bahwa musim pemijahan ikan ini di India berlangsung hampir sepanjang tahun dengan 2 puncak yaitu antara bulan Juli-Oktober dan bulan Januari-April.

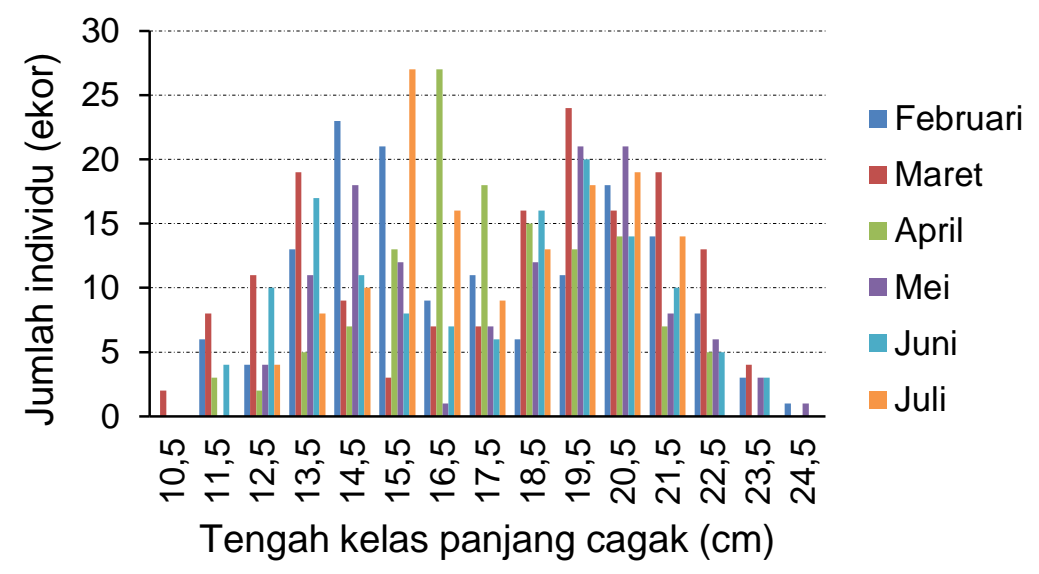

Jurnal Frontiers Vol 1 No 3, Desember 2018 
Gambar 6. Distribusi bulanan ukuran panjang ikan S. crumenophthalmus

\section{KESIMPULAN}

1. Pola pertumbuhan ikan $S$. crumenophthalmus jantan dan betina bersifat allometrik positif.

2. Nisbah kelamin ikan jantan dan betina dalam kondisi seimbang.

3. Faktor kondisi relatif ikan jantan dan betina berfluktuasi dengan nilai kisaran 0,691 - 1,422 untuk ikan jantan dan ikan betina berkisar $0,701-2,238$ mengindikasikan bahwa bentuk tubuh ikan S. crumenophthalmus tergolong kurang pipih atau fusiform.

4. Sebaran frekuensi panjang ikan $S$. crumenophthalmus jantan didominasi pada ukuran interval kelas panjang 19$20 \mathrm{~cm}$ dan ikan betina pada ukuran interval kelas panjang 20-21 cm.

\section{DAFTAR PUSTAKA}

Anderson R.O \& S.J Gutreuter. (1983). Length-weight and associated structural indices. In Nielsen L. and Johnson D. (eds) Fisheries techniques. Bethesda, MD: American Fisheries Society, pp. 283-300.

Andreu-Soler A, F.J.O. Paterna \& M. Torralva. (2006). A review of length weigth relationships of fish from the Segura River Basin (SE Iberian Peninsula) J. Appl. Ichthyol. 22: 295-296.

Ayo-Alalusi C.I. (2014). Length weight relationship, condition faktor and sex ratio of African Mud Catfish (Clarias gariepinus) reared in flow-through systems tanks. Journal of Fisheries and Aqutic Science 9(5): 430-434.

Badan Pusat Statistik Kota Bitung. (2016). Statistik Daerah Kota Bitung 2016.
Katalog BPS: 1102001.7172. No. Publikasi: 717206.080. vii+44 hlm.

Bagenal T.B \& A.T Tesch. (1978) Conditions and growth patterns in fresh water Habitats. Oxford: Blackwell Scientific Publications.

Ball D.V \& K.V Rao. (1984). Marine fisheries. Tata McGraw-Hill Publishing Company, New Delhi, p.51-73.

Cervigon F, R. Cipriani, W. Fischer, L. Garibaldi, M. Hendrickx, A.J. Lemus, R. Marquez, J.M. Piutiers, G. Robaina \& B. Rodriguez. (1992). Sheets FAO species identification for fishery puopose. Field guide to the commercial marine and brackish species aquas of the northern coast of South America. FAO, Rome. 513p.

Clarke A.T \& L.A Privitera. (1995). Reproductive Biology of Two Hawaiian Pelagic Carangid Fishes, the Bigeye Scad, Selar crumenophthalmus, and the Round scad, Decapturus macarellus. Bulletin of Marine Science 56(1):33-47.

Dinas Perikanan dan Kelautan Kota Bitung. (2014). Laporan Tahunan Dinas Kelautan dan Perikanan Kota Bitung Tahun.

Direktorat Jenderal Perikanan Tangkap. (2013). Standar Klasifikasi Statistik Jenis Ikan Perikanan Laut. Kementerian Kelautan dan Perikanan. Jakarta. 188 hlm.

Echem R. T \& D.N Minoza. (2017). Biological characterization of bigeye scad Selar 
crumenophthalmus

Bloch

(Osteichthyes: Carangidae). Nature

Science Chapter II. Advance

Research Journal of MultiDisciplinary Discoveries 9(1): 4-8.

Effendie M. I. (1997). Biologi Perikanan. Yayasan Pustaka Nusatama. Yogyakarta. $163 \mathrm{hlm}$.

Froese R \& D. Pauly. (2014). Fish Base. October 2014 version. N.p.: FishBase, 2014. World Wide Web electronic publication (www.fishbase.org).

Froese R. (2006). Cube law, condition factor and weight-length relationships: history, metaanalysis and recommendations. Journal of Applied Ichthyology 22(4): 241253.

Kartamihardja E.S. (2015). Pengkajian Stok (Stock Assesment) Ikan di Perairan Umum Daratan Indonesia. Komisi Nasional Pengkajian Stok Sumber Daya Ikan. Pusat Penelitian Pengelolaan Perikanan dan Konservasi Sumber Daya Ikan. Protokol Pengkajian Stok Sumber Daya Ikan. Komisi Nasional Pengkajian Sumber Daya Ikan, hlm. 95-119.

Kharat S.S., Y.K. Khillare \& N. Dahanukar. (2008). Allometric Scalling in Growth and Reproduction of a Fresh Waters Loach Nemacheilus mooreh (Sykes, 1893). Electronic Journal of Ichthyology (1): 8-17.

Kishakudan S.J \& P. S. Reddy. (2012). Length-weigth relationship in three spesies of silver bellies from Chennai coast. Indian J. Fish 59(3): 65-68.
Lemma B, T. Tessema \& R. Fessehaie. (2015). Distribution, abundance and socio-economic impacts of invasive plant species (IPS) in Borana and Guji Zones of Oromia National Regional State, Ethiopia. Journal of Agricultural Science and Review 4(9): 271-279.

Mansor M.I, A. Syed \& Y. Abdul Hamid. (1996). Population structure of small pelagic fishes off the east coast of peninsular Malaysia. Malaysia: Department of fisheries Malaysia, Ministry of Agriculture, $27 \mathrm{pp}$.

Mazlan A.G \& Y.G Seah. (2006). Meristic and length-weigth relationship of the Ponyfish (Leiognathidae) in the Coastal water of Pulau SibuTinggi, Johor, Malaysia. Malays. Appl.Biol. 35(1):27-35.

Merta I. G. S. (1993). Hubungan panjang dan bobot dan faktor kondisi ikan lemuru,Sardinella lemuru Bleeker, 1853 dari perairan Selat Bali. Jurnal Penelitian Perikanan Laut. 73 : 35-44.

Miranda R, J. Oscoz, P.M. Leunda \& M.C. Escale. (2006). Weigth-Length Relationships of Cyprinid Fishes of the Iberian Peninsula. J. Appl. Ichthyol. 22: 297-298.

Panda D, A.K. Jaiswar, S.D. Sarkar \& S.K. Chakraborty. (2015). Growth, mortality and exploitation of bigeye scad, Selar crumenophthalmus off Mumbai north-west coast India. Journal of the Marine Biological Association of UK. p.1-6. DOI: $10.1017 / \mathrm{S} 0025315415001459$.

Pauly D \& P. Martosubroto. (1996). 
Baseline Studies of Biodiversity : The Fish Resources of Western Indonesia. International Center for Living Aquatic Resources Management, Philippines; Directorate General of Fisheries, Ministry of Agriculture, Indonesia; German Agency for Technical Cooperation, Germany. ICLARM Stud. Rev (23): 312p.

Pelabuhan Perikanan Samudera Bitung. (2015) Laporan Statistik. Direktorat Jenderal Perikanan Tangkap. Kementerian Kelautan dan Perikanan. $41 \mathrm{hlm}$.

Rahman Y, T.R. Setyawati dan A.H. Yanti. (2013). Karakteristik Populasi Ikan Biawan (Helostoma temminckii Cuvier) di Danau Kelubi Kecamatan Tayan Hilir. Jurnal Protobiont 2(2): 80-86.

Roos D, O. Roux \& F. Conand. (2007). Notes on the biology of the bigeye scad, Selar crumenophthalmus (Carangidae) around Reunion Island, southwest Indian Ocean. Scientia Marina 71:137-144.

Roux O \& F. Conand. (2000). Feeding habits of the bigeye scar, Selar crumenophthlamus (Caragidae), in La Reunion Island Water (SouthWestern Indian Ocean). Cybium 200 24(2): 173-179.

Saranga R, H. Santoso, N. Tumanduk dan H. Ondang. (2016). Kajian morfometrik dan molekuler ikan selar mata besar (Oci) dan selar mata kecil (Tude) (Family Carangidae) yang tertangkap di perairan sekitar Bitung. Prosiding. Seminar Nasional Pengelolaan Perikanan Pelagis. Fakultas Perikanan dan Ilmu Kelautan Universitas Brawijaya, hlm. 68-72.
Siwat V, A. Ambariyanto \& I. Widowati. (2016). Biometrics of bigeye scad, Selar crumenophthalmus and shrimp scad, Alepes djedaba from Semarang waters, Indonesia. $A A C L$ Bioflux 9 (4): 915-922.

Smith-Veniz W.F. (2003) Carangidae. In Carpenter K.E. (ed.) The living marine resources of the western central Atlantic. FAO species identification guide for fishery purposes, Volume 3, Part 2. Rome: FAO, pp. 1426-1468.

Smith-Vaniz W.F., Collette B.B. and Luckhurst B.E. (1999) Fishes of Bermuda: History, zoogeography, annotated checklist and identification keys. Lawrence, KS: American Society of Ichthyologists and Herpetologists Publ. 4, 424 pp

Smith-Vaniz W.F, J. T Williams, J. Brown, M. Curtis \& F.P Amargos. (2015). Selar crumenophthalmus. The IUCN Red List of Threatened Species 2015: e.T190388A16510647. 7pp.

Tsoumani M, R. Liasko, P. Moutsaki, I. Kagalou \& I. Leonardos. (2006). Length-weight relationships of an invasive cyprinid fish (Carassius gibelio) from 12 Greek lakes in relation to their trophic states. $J$. Appl. Ichthyol. 22(4): 281-284.

Venkataramani, V.K, N. Ramanathan \& K. Venkataramanujam. (1995). "Breeding biology of a carangid fish Selaroides leptolepis Cuv. (Perciformes) along Tuticorin, southeast coast of India". Indian Journal of Marine Sciences 24 (4): 207-210. 
R. Saranga, J.I. Manengkey, Asia. Jurnal Sains dan Teknologi, Universitas Negeri Manado \& M. Z. Arifin www.unima.ac.id/lppm/efrontiers

Wilson D. S \& A.B Clarke. (1996). The shy and the bold. Natural History 9(96): 26-28. 
R. Saranga, J.I. Manengkey, Asia. Jurnal Sains dan Teknologi, Universitas Negeri Manado \& M. Z. Arifin www.unima.ac.id/lppm/efrontiers

\section{THIS PAGE IS INTENTIONALLY LEFT BLANK}

